\title{
PHYSICAL MODELING OF DIATREME EMPLACEMENT
}

T. S. Woolsey, Physical Sciences Div., Lincoln Land Community College, Springfield, Illinois 62703

M. E. McCallum, and S. A. Schumm, Department of Earth Resources, Colorado State Univ., Ft. Collins, Colo. 80521

Fluidization or mobilization of particulate materials by upward moving high velocity gas is the mechanism suggested by most field investigators for emplacement of diatremes and development of associated structures. A series of experiments was conducted with small scale models utilizing fluidization techniques similar to those developed by chemical engineers for industrial applications. These experiments generated a number of structural and textural features that are similar to features observed in diatremes.

Containers were constructed in various cylindrical, parallel plate, and box-like configurations. The cylindrical containers were $20 \mathrm{~cm}$ high and ranged in diameter from 7 to $15 \mathrm{~cm}$. Parallel plate containers were $4 \mathrm{~cm}$ thick, $35 \mathrm{~cm}$ high and both 21 and $100 \mathrm{~cm}$ wide. The two box containers used were $30 \mathrm{x} 30 \mathrm{~cm}$ and $90 \times 90 \mathrm{~cm}$ in plan and $17 \mathrm{~cm}$ deep. Some model containers were designed for sectioning while others were constructed with plexiglass walls to allow direct observation of developing features.

Gas was supplied to the base of the containers via a $2 \mathrm{~cm}$ diameter screened orifice and allowed to pass upward through the contents and out the top which was open to the atmosphere. Gas used in all experiments was compressed air from a large volume source piped to the models through a pressure regulator and float-type flow meter.

Particulate mixtures used ranged from clay-size (powdered kaolinite) to $0.5 \mathrm{~cm}$ gravel. Materials were arranged in layers that varied in experiments from layers or different particle sizes to homogeneous mixtures in which contrasting colors served as marker horizons. A few experiments utilized layers of different size particles in dipping beds or with bed pinch-outs. Surface crusts and subsurface layers of poorly consolidated silt were used to study the effects of fluidization on low-strength, highly friable materials.

Most experiments were characterized by the early development of surface doming and, where a cohesive or semi-consolidated surface layer was present, associated ring and radial fractures. A rapid upward propagation of intricate subsurface fracture patterns was generated with increasing gas pressures during tests with cohesive materials, and subsurface gas-filled cavities with arched roofs formed in many of the scale simulations. Fluidized 
circulation cells developed below these voids and slowly moved upward to the surface by stoping (Fig. 1A). Multiple vertically aligned voids were observed simultaneously in several cases. In some tests where particularly explosive blowout occurred, formerly horizontal beds in the surrounding strata were deformed into compressional folds. When gas flow was terminated prior to breaching of the surface by the circulation cell, some subsidence of overlying beds was observed. This might suggest that some cryptovolcanic features exhibiting circular subsidence structure and an absence of volcanic material may be the result of diatremes that never reached the surface.

Conduits were typically funnel-shaped, widening toward the surface, and eruption usually produced a maar type crater with a diameter several times that of the lower part of the conduit. Such configuration resembles diatremes that have been revealed to considerable depth, such as the Kimberley Pipe in S. Africa, and is similar to shapes derived through theoretical calculation by McGetchin (1968). Subsidence in the models occurred concentric to the mobilization conduit, and surface blocks were transported down along pipe margins. Blocks and slabs of highly friable, low strength materials subsided in the fluidized convection cells, but they showed little attrition unless circulated many times (Fig. 1B).

In a few experiments, a slow bubbling surface eruption was accompanied by an air-fall size sorting and bedding of particulate matter. Such bedding was most notable when mixtures of $0.25 \mathrm{~mm}$ sand and 200 mesh marble dust (finer than $0.074 \mathrm{~mm}$ ) were used. The bedded material was carried down the pipe by slow marginal subsidence concurrent with central eruption (Fig. IC). Final disposition closely approximates numerous field conditions, where moderately to steeply dipping bedded tuffs occur deep in pipes and are cross-cut by central zones of unbedded breccia (e.g., Cloos, 1941; Hearn, 1968). Crude segregations of unbedded pipe materials were noted in several experiments, the finest particulate mixtures found toward pipe centers and coarse aggregates near the margins. Spheroidal pellets possibly analogous to the pelletal lapilli described by Rust (1937) and Hearn (1968) were formed by accretion of clay-size particles on larger grains during bubbling fluidization. 


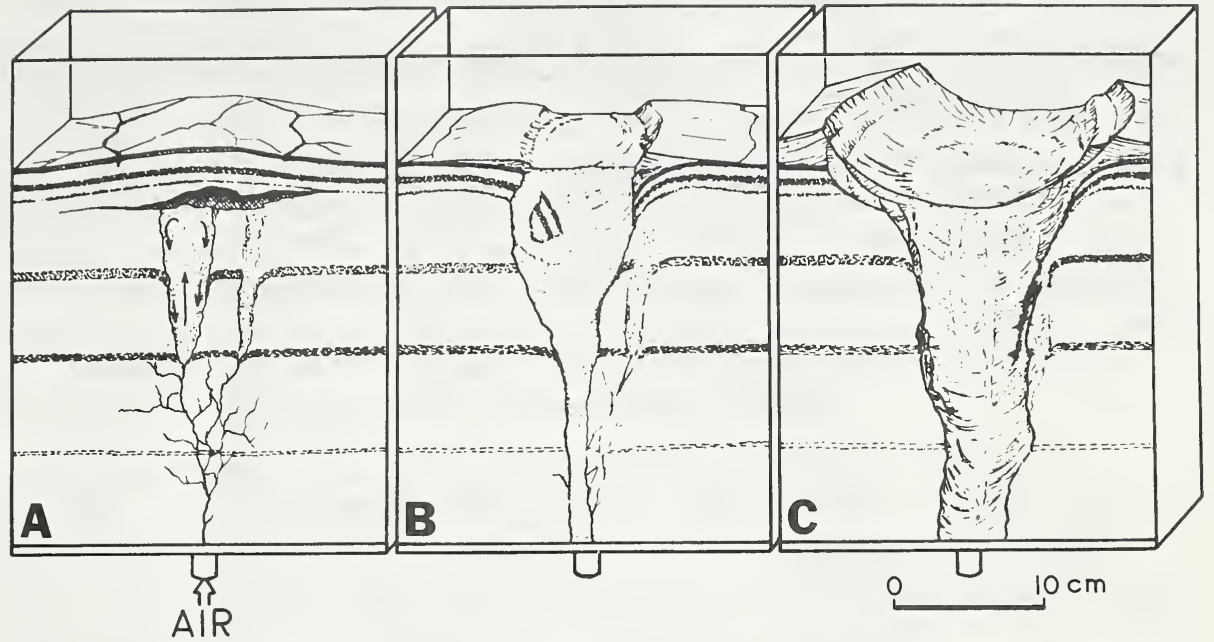

Fig. 1. Diagrammatic series showing principle features developed in model diatremes.

A. Compressed air entering base of container propagates fractures in cohesive clay or marble dust mixture. Two subsurface fluidized circulation cells develop below void produced by fracture and uplift of upper layers. Doming of the surface with ring and radial fractures results from uplift. B. Breakthrough to surface occurred above main fluidization cell and smaller cell has become inactive. Surface layers display inward dip on right and detachment and descent of a surface slab on left. A cone of bedded ejecta has begun forming.

C. Continued bubbling circulation has built a larger bedded ejecta cone with rotational slumping into crater. Smears and slices of adjacent strata have descended along pipe margins. Bedded ejecta is carried downward during continued bubbling fluidization accentuating saucer-like form by drag along the pipe walls. Faint channelways may be seen where higher velocity upward moving gas has cleared out fines. Minor dog-leg offset may be related to variation in competency of beds. 
References Cited

Cloos, H., 1941, Geol. Rundschau, 32, 709-800.

Hearn, B. C., 1968, Science, 159, 622-625.

McGetchin, T. R., 1968, Calif. Inst. Tech., unpub. Ph.D. thesis, $405 \mathrm{p}$.

Rust, G. W., 1937, Jour. Geol., 45, 48-75. 